\title{
Rhetorical and Persuasive Strategies Employed by Imran Khan in his Victory Speech: A Socio-Political Discourse Analysis
}

\author{
Unaiza Saeed ${ }^{1}$, Muhammad Zammad Aslam², Abdulrehman Khan ${ }^{1}$, Mahnoor Khan ${ }^{1}$, Maria Atiq ${ }^{1}$ \& Humayun \\ Bhatti \\ ${ }^{1}$ National College of Business Administration \& Economics, Multan, Pakistan \\ ${ }^{2}$ National University of Modern Languages, Islamabad, Pakistan \\ Correspondence: Muhammad Zammad Aslam, National University of Modern Languages, Islamabad, Pakistan. \\ E-mail: zammad.aslam@gmail.com
}

Received: December 17, 2019 Accepted: February 2, 2020 Online Published: February 23, 2020

doi:10.5539/ijel.v10n2p349 URL: https://doi.org/10.5539/ijel.v10n2p349

\begin{abstract}
This study aims to explore the rhetorical and persuasive strategies employed by a political leader to propagate his ideology using language. It intends to critically analyze the victory speech of Pakistani Premier Imran Khan (IK) - the Chairman of Pakistan Tehreek-e-Insaf (PTI) — which he delivered at the Prime Minister House, Islamabad, after being elected as the 22nd Premier of Pakistan in 2018. The researchers attempt to unveil and analyze critically the strategies that worked behind this speech to persuade the audience. Different linguistic tools used for projecting and achieving political power have been identified and scrutinized. The qualitative analysis of the speech is based on theory of Aristotle's Rhetoric; Ethos, Pathos, Logos and other persuasive strategies like use of personal pronoun, predication strategy, and positive self-presentation and negative others-presentation employed by IK, and further to study how language carries the power of transforming the perception and political views of people. The findings suggest that political discourse is intentionally crafted to communicate and persuade people about specific ideologies located in the discourse in an implicit way and IK uses the Aristotelian rhetorical model comprising of rhetoric, predication strategy, and self-presentation and negative Others-presentation strategy to persuade his audience to follow his hidden agendas.
\end{abstract}

Keywords: discourse, political discourse, persuasion, ideology, rhetorical strategy, persuasive strategy, Aristotle's theory

\section{Introduction}

The issue of persuasion being a huge part of politics has been deliberated for centuries, and an effective public speaker often uses the rhetorical tools of persuasion (Baig et al., 2019, p. 252). Therefore, one cannot separate politics and persuasion. Language plays a pivotal role in constructing identity and ideology (Aazam et al., 2019, p. 162), therefore, political leaders use language i.e., political discourse, to persuade others (Kennedy, 2007 as cited in Nurrosyidah, 2016, p. 1). As this fact that language would be said a system and this system consists of words that have sense and convey meanings (Baig et al., 2020, p. 230). Therefore, through language, persuasive strategies are used across the globe by well-known political leaders such as Barack Obama, Joko Widodo, Dr. Roahuani, and Imran Khan. Because Imran Khan is the premier of Pakistan, his speeches have often influenced the masses inside and outside the country, including many persuasive techniques and this study analyzes the use of persuasive strategies in his victory speech. It is believed that political discourse concerns the involvement of the audience in decision making with the help of valid information and logical message passed by the speaker (Johnson \& Jonson, 2000 as cited in Nurrosyidah, 2016, p. 1). Hence, political speeches are loaded with persuasive strategies.

Language is seen as a multi-layered means of communication through which political leaders persuade and influence the audience. Words and their combinations are socially, politically, racially and economically loaded (Khalil et al., 2017). Language carries various hidden agendas, to understand them, critical discourse analysis offers the best analytical tools. It enables us to understand the hidden meaning embedded in discourse. Discourse is defined as the use of language for communication and it refers to sentences that are grammatically well-formed, but which do not necessarily have to be grammatical (Cook, 1992). It is described as a part of society and the use of language as a social practice (Fairclough, 1996, 2003 as cited in Baig et al., 2020, p. 72; 
Hamidi \& Mirzaee, 2012), hence, the discourse would not be neutral since it is caught up in political, social, racial, religious and cultural formation (Atkins, 2002 as cited in Hamidi \& Mirzaee, 2012). However, for the nature of this research, the general idea of discourse as text in setting (Van Dijk's, 1977 as cited in Horvath, p. 45), seen as "information that is obligated for empirical examination" is taken in account (Titscher et al., 1998 as cited in Horváth, p. 45). Furthermore, the concept of discourse, power, and ideologies are intimately connected with each other. Similarly, politics would be an effort for power in order to put certain political, economic and social ideas into practical application. Power relations should be regarded as discursive, and social relations of power can be exercised and negotiated in and through discourse for every political action that can be prepared, accompanied, influenced and delivered by language. Politicians may achieve their political goals by physical enforcement but there would be another way that is more tactful - the use of persuasive techniques in order to persuade people to act in a special way they intend (Jalilifar \& Alavi, 2011 as cited in Norali \& Rezaei, 2016).

Hence, many techniques and strategies have been introduced about persuasion which is included in rhetoric. Additionally, rhetoric is the art of persuading people with language (Kennedy, 2007 as cited in Nurrosyidah, 2016, p. 1), For instance, Fairclough (1992) argues that people understand each other's actions through discourse as a responsibility (Aazam et al., 2019, p. 192; Baig et al., 2019, p. 70). Furthermore, in this study, the researchers investigate the use of different persuasive strategies in Premier of Pakistan, Imran Khan's victory speech.

The purpose of this study is to locate the persuasive strategies Prime Minister Imran Khan uses in his victory speech to persuade his audience into believing in his political ideologies and to manipulate people's political views. Imran Khan delivered this speech on 26th July 2018, after being declared the prime minister of Pakistan, from the Prime Minister House, Islamabad. The researchers select this speech of Imran Khan for analysis because as an influential person and Prime Minister of Pakistan, society monitors his speeches, therefore, he has much influence on people. Additionally, it has importance in the politics of Pakistan which is a diverse society having attachments with certain political and religious views. Besides, political commentators, analysts, and the common public hailed this speech as 'mature', 'balanced' and 'encouraging' (News Desk, 2018, July 26). Based on the above-mentioned reason, the researchers take this topic as a fit subject for detailed explorations.

The study is significant in multiple aspects as it seeks to identify both macro and micro-elements of political talk which bear a semblance of certain influences. Aristotle's view has always predominantly exercised in dominatable influences on renowned speakers of the world and every new leader without being aware of it follows the speakers. The study puts in the right perspective the means and manners of language use favored by Aristotle.

The objectives of the study are; i) to analyze the use of Aristotle's Rhetorical strategies in Imran Khan's post-election victory speech and; ii) to identify the different persuasive strategies Prime Minister Imran Khan uses in his speech to influence political views of people. The researchers have tried to answer the research questions: a) Given the rhetorical strategies introduced by Aristotle, how does Prime Minister Imran Khan use these strategies to persuade people into believing his intended ideologies? b) What are the different persuasive strategies used by Prime Minister Imran Khan to influence the political views of the masses?

\section{Theoretical Framework}

\subsection{Political Discourse and Aristotelian Rhetoric}

Political discourse is the text or talk of professional politicians or political institutions; president, prime ministers, other members of government, parliament or political parties at local, national or international levels (Dijk, 1997, p. 12). Basically, a political discourse refers to the use of language in parliaments, debates, speeches by political leaders, etc.; political context. It can be in the form of writing and/or conversation. It regards basic components of politics such as issues of power, conflict/control and domination (Peng, 2007 as cited in Ko, 2015, p. 115). In this sense, politics can be regarded as the effort for power with the purpose of setting specific political, social or economic ideas into practical application and political discourse as the use of language to achieve this purpose. In this context, political leaders seek to persuade people to achieve their purpose. For this, they use different persuasive strategies.

'Persuasion' is defined as an art of using language to communicate with the intention of making the listener do something according to the speaker's will (Simons, 1976 as cited in Alghamdi \& Rand, 2019, p. 85). This study uses Aristotle's rhetorical theory (350 B.C.E) of persuasion and other persuasive strategies; use of the personal pronoun, word choice, positive self-presentation, and negative others presentation and predication strategy (Khalil et al., 2017). 
Aristotle suggests three strategies of persuasion used by the speaker to convince the audience; ethos (the orator's character), pathos (the emotions of the audience), and logos (the rationality of the orator's arguments) (Ko, 2015, p. 115). First, ethos is the appeal to one's character. Aristotle uses ethos to refer to the speaker's character as it appears (Connors, 1979 as cited in Ting, 2018, p. 234). For instance, if we believe that a speaker has good sense, good moral character, and goodwill, we are inclined to believe what that speaker says to us. Second, pathos is the emotional appeal that targets the audience's feelings in order to have a connection with the speaker (Ting, 2018). Emotions, such as anger, pity, fear and their opposites influence our rational judgments. That is why political leaders are directed towards moving the audience's emotions. Third, logos is persuasion using logic, reasoning, and facts (Ting, 2018). This theory is acceptable and rational to be used in analyzing persuasive strategies in political speeches, thus, it is used in this research.

\subsection{Use of Personal Pronouns}

Pronouns, among other linguistic features, can shed light on how participants project themselves and how they express associations with others. Inclusive pronoun 'we' (speaker and listener) can be used as a strategy to express solidarity; whereas, exclusive pronoun 'we' (speaker and other/s excluding the listener) can be used to share responsibility, that is, actions are not only the responsibility of one individual (Wilson, 1990 as cited in Partington, 2003). The first-person pronouns can be used by politicians in their strategies "to gain the people's allegiance, to have them believe that the decisions that are being made are the right ones" (Wilson, 1990, p. 71, as cited in Partington, 2003). On the other hand, the use of the inclusive pronoun 'we' may indicate the exclusion of some other groups, which implies a division between us and them. This study seeks to examine the use of the personal pronoun used by Imran Khan in his victory speech to persuade his audience.

\subsection{Predication Strategy}

Predication strategy is the persuasion strategy used by speakers to persuade the audience by associating stereotypes and attributes of negative or positive traits to the in-groups or out-groups (Sharif, 2015, p. 26). It correlates mostly with the use of a nomination strategy regarding positive self-presentation and negative other presentations. Prediction strategy in Prime Minister Imran Khan's speech is sought to be explored in the study.

\subsection{Socio-Cognitive Theory}

There are some other important theories that may be used to analyze persuasion in political discourse; one of them is socio-cognitive theory (Van Dijk, 1991 as cited in Khalil et al., 2017) which the researchers use in this research. This approach to discourse is described as a general theory or philosophy of social constructionism, which states that social members construct the social and political 'reality'. It emphasizes that such 'constructions' are mental representations, implemented by the brain and should be taken seriously and analyzed in detail. This theory presents that mental presentations are expressed by emphasizing the good properties of 'Us' (in-group) and bad properties of 'Them' (out-group) and expresses underlying attitudes and ideologies via discourse either written or spoken (Van Dijk, 2016). This theory is employed by political leaders to gain the trust of the audience and to persuade them into believing their intended ideologies, beliefs, views and mindset. This research analyzes how Imran Khan would associate good properties with himself and negative properties to other parties to make people trust him.

\section{Research Methodology}

\subsection{Research Design}

The research is qualitative in nature has used the analytical framework for a comprehensive understanding of rhetoric and persuasive strategies used in PM Imran Khan's speech. Qualitative research has preferred a complete understanding of underlying reasons, meanings, values, beliefs, opinions, and social problems. This approach to research mainly focuses on the meanings, concepts, characteristics, metaphors, and description of things rather than their counts or measures.

This research is categorized as an exploratory research design. Exploratory qualitative research aims at providing insight into a phenomenon without any addition or reduction in data. Similarly, current research is designed to explore and understand the rhetoric and persuasive strategies used in Imran Khan's first speech after taking oath of the premiership and to help in identifying different strategies hidden in the data by analyzing it based on Aristotle's rhetoric and persuasive strategies. For this purpose, the data are in the form of the text of the selected speech.

Moreover, data are transcribed, translated into the English language and analyzed employing the purposive sampling technique and the study is delimited to the specific text relevant and related to the aspects from the speech which relate to the given model. 


\section{Data Analysis and Discussion}

\subsection{Appeal to One's Character-Ethos}

Imran Khan seeks to present himself in a manner that makes people respect and listen to him. He uses this technique of Ethos to have people put their trust in him as their savior and leader. In the start, he thanks the people, who worked with him in 22 years of struggle,

"First of all, today, I would like to thank all my workers who started with me 22 years ago in this movement, in this struggle".

This statement is from the start of Imran Khan's victory speech. He pays regard to those who worked with him. Thanking those who started with him in his struggle of being in politics and having the current position as Prime Minister portrays him as humble. It also helps him in creating an image of someone who does not forget other's efforts, thus presenting him as loyal. He also mentions the efforts that made him stand as Prime Minister today; '22 years ago', 'in this movement', 'in this struggle' are the words that identify this statement as ethos. Imran Khan started his career as a politician in 1996; from 1996 to 2018 it has been exactly 22 years as Imran Khan says. His use of words '22 years' 'in this struggle' show his good image as a hard worker and determined person. Hence, using this strategy at the start of the speech may help him to portray his character to appeal to the audience so that they may be able to believe whatever he says.

Next, he talks about his purpose by saying:

"I entered politics 22 years ago and my purpose was to make our country such that it was originally meant to be, which means the dream that Allama Iqbal had of a prosperous Islamic state where we can lead by example, in front of the world".

Imran Khan's purpose of stepping into politics can be seen as an attempt to arise an appeal of his character in the minds of the audience as he expresses his reason that is acceptable for the whole nation. He mentions the "dream of Allama Iqbal" and "prosperous Islamic state" and these both concepts are easily understandable for Pakistanis. These concepts allude to the very ideological beliefs of most of the Pakistani masses envision such a state to be established.

"Dream of Iqbal" makes reference to the "prosperous Islamic state" that the spiritual and intellectual founder of Pakistan, Allama Muhammad Iqbal dreamt of. He was the one who convinced Muhammad Ali Jinnah, the founder of Pakistan, to return to the Subcontinent and become a part of politics and elaborated the concept of an independent Islamic state for Muslim-majority provinces, in his Allahabad speech. He became the first one to articulate a vision that became a Two-Nation-Theory afterward. His dream for Pakistan directs the mind to a state where peace prevails, Islamic laws are implemented, the culture of Islam is exercised, Muslims live with tranquility and minority lives as per their religion. The sincerity of Allama Iqbal makes him the favorite personality of the Pakistani nation and his concept of a "prosperous Islamic state" a model for the development of Pakistan. Therefore, speaking of the 'dream of Iqbal' and 'prosperous Islamic state' creates a positive image of Imran Khan as a learned person who knows about the history and a concerned leader whose mission is to make Pakistan the way Allama Muhammad Iqbal dreamt of. As people of Pakistan have emotional attachments with Allama Iqbal, they are more likely to be persuaded by such reference.

\subsubsection{Use of Personal Pronoun}

The excessive use of the personal pronoun ' $I$ ' by Imran Khan shows a positive presentation of himself. It can also be an attempt by the individual speaker to place himself above or outside the shared responsibility of his colleagues. Moreover, He uses ' $I$ ' while describing how he has been struggling for the past 22 years,

"I would like to thank all my workers who started with me 22 years ago in this movement, in this struggle."

Imran Khan seems to show his personal attitude towards ' $I$ ' when he thanks the workers who started with him in this struggle. The positive attachment of the word 'struggle' while talking about himself and his workers may rightly be an attempt to highlight his accomplishments. In this way, he may be able to build his good repute in the minds of his so as audience to persuade them later.

\subsection{Appeals to Emotions-Pathos}

To pursue the audience into his agendas, Imran Khan uses the rhetorical strategy of pathos-appeals to the emotions of the audience in order to have a strong connection with them.

Imran Khan tries to convince the audience to pay taxes by saying:

"Hence, we've to think that the tax we pay, we're giving it for the sake of Allah, like how we pay 'Zakat"'. 
Imran Khan asks his audience to pay tax for the sake of Allah. In Muslim communities, doing something for the sake of Allah means that when a person does something for Allah's (God) sake, he will be rewarded much more than what he has done, and Allah will give him in this life and in the life after death. So, Imran Khan tries to make his audience emotional by requesting them to pay tax for Allah's sake so that they may have much more than they spend. Next, he says 'like how we pay Zakat'. The word 'Zakat' serves as a source of emotional appeal for the audience. 'Zakat' is an Arabic term that means charitable contribution. It is one of the five pillars of Islam and is mandatory for all the Muslims who come under the criteria of wealth. So, Imran Khan tries to convince his audience to get inclined to paying tax as their obligation by referencing it to 'Zakat'.

Imran Khan addresses his audience to talk about the arrest of corrupt people and says,

"However, you have to stand your ground alongside me because either this country can be saved, or these corrupt people can be saved".

Imran Khan attempts to persuade his addressees to support him and oppose the corrupt people when they make noise over their arrests, by making an appeal to their emotions. The words 'corrupt people' can be used for anyone who does corruption but keeping the exact context in mind, Imran Khan seems to make a special reference to the people of PML-N and PPP, the major opposition and former rulers. He, then, uses the words "either this country can be saved, or these corrupt people can be saved" it means that the people of Pakistan have to decide whether they want to save Pakistan or these corrupt people, and in order to save the country, they have to stand with him rather than other parties. He, very skillfully, not only reduce the chance of support for 'others' but also increases the possibilities of having back of nation for 'him'.

\subsection{Appeal to Logic-Logos}

Imran Khan, along with ethos and pathos, uses the logical appeal which is logos. He provides a logical discussion in addition to the proofs. As when he talks about the debts of Pakistan, he uses a proper numeric data and tells how the problem of debt has developed.

Imran Khan talks about the people who have done money laundering. He states his opinion with the support of a report of the US State Department,

“The people who've done money laundering, there's a report by the US State Department, which says money laundering of worth 10 billion dollars takes place in Pakistan every year."

Imran Khan declares that many people have done money laundering in Pakistan and then to support his argument he put forwards "a report by the US State Department". That report says that "says money laundering of worth 10 billion dollars takes place in Pakistan every year." It is a strong piece of information to use as proof to make his audience believe in what he says. Imran Khan may choose this source of information; "US State Department" because the US is believed to be the most dominant and superpower in the world right now and people believe in what it says. So, when Imran Khan says that people of Pakistan do money laundering especially those in power and have lots of money and as gives proof the report of the US State Department which says the same, the audience tends to believe him more easily than usual.

\subsection{Predication Strategy}

Imran Khan associates certain stereotypes with major political parties which are realized through the language used by him in his under-examination speech. As, when he talks about the debt Pakistan owes to other countries and the progress of Pakistan, he states,

"The debt that Pakistan owes today, it is 28 trillion rupees. Ten years ago, Pakistan has a debt of 6 trillion rupees, which means that our total debts from the 60-year-old history of Pakistan summed up to Rs 6 thousand trillion. In 2008, it went up to 15 trillion rupees from 6 trillion rupees. And in 2013, it went from 15 trillion rupees to 28 trillion rupees. That means Pakistan is so much deep in debts just think about the debts of our entire 60-year history, and the debts of the last decade alone. This is something which hopefully we will reveal in front of you, "where did all this money vanish?" if such high sky debts were taken, "what' was done with all that money."

In the above statement, Imran Khan says that "The debt that Pakistan owes today, it is 28 trillion rupees" and ten years ago it was "a debt of 6 trillion rupees" but, "In 2008, it went up to 15 trillion rupees from 6 trillion rupees" which was in the reign of PPP. PPP stands for Pakistan People's Party and it under the presidency of Benazir Bhutto, who died during the campaign, ruled the country twice in the past. After that, her husband Asif Ali Zardari took the presiding chair. Then Imran Khan says that "in 2013, it went from 15 trillion rupees to 28 trillion rupees." which was the reign of PML-N which is abbreviation of Pakistan Muslim League (N) that was 
under the presidency of Nawaz Sharif. Imran Khan associates the stereotype that these two parties must have been stealing and using the debt on their personal expenses rather than Pakistan by asking, "Where did all this money vanish?" Imran Khan indirectly stereotypes PPP and PTI that the member of these two parties especially their leaders Zardari and Sharif have been robbing the country by taking debts and spending on themselves instead of for the betterment of the country.

Then, after talking about all the money borrowed during the past years for Pakistan by its leaders and the debts that are owed now, he states,

"Today I am presenting all these things in front of you because I want you to realize that if we continue this, we are heading towards disaster."

Imran Khan mentions that the real issue our country faces is the foreign debt worth 60 billion dollars that was taken by PPP, and the debt of 95 billion taken by PML-N from 2013-2018. And then he declares that if we continue to do what these politicians have been doing "we are heading towards disaster". By using a predication strategy, Imran Khan tries to associate stereotypes with PPP and PML-N that if the people of Pakistan choose these parties one more time, there will be a chaotic future waiting for them.

\subsection{Positive Self-Presentation and Negative Other-Presentation}

Imran Khan, in this speech, presents himself and his party as having good traits and presents other parties and their leaders as having negative traits in order to gain support from his audience and to turn them against other parties.

To achieve this purpose, Imran Khan while talking about the mess created by other politicians says,

"And it is all because of these foreign debts of ours that have increased so rapidly that the biggest challenge we face now is how to pay off these debts. I will come back to this and explain how we can fix this problem."

Prior to this, Imran Khan's refers to the two known parties of Pakistan, PML-N, and PPP, as the most loan taker because Pakistan has been drowning into debt since they came into power. He declares paying off those debts as "the biggest challenge we face". This declaration is also significant as he mentions in the next line that he will "explain how we can fix this problem". This statement may be an effort by Imran Khan to present himself as an empathetic and supportive person and other party members as ruthless who damaged Pakistan. It may be concluded that Imran Khan wants to create an image of a hero by solving the problems of Pakistan caused by other politicians. The use of this strategy is beneficial for Imran Khan to have people by his side y gaining their trust as a good person.

Later, while talking about the condition of FBR, he declares,

"I promise to you today that first, I'm going to fix FBR. Our first effort will be to address the extensive corruption in FBR."

The above statement makes a clear point that Imran Khan wants his audience to know that he will fix FBR for them. FBR is abbreviated for the Federal Board of Revenue which is a Pakistani institute that investigates tax crimes and money laundering. Imran Khan's use of the word 'fix' can be analyzed that the system of FBR is demolished by the negligence of previous governments. So, the word 'fix' can also be considered as the effort of Imran Khan to show him as a problem solver. In this way, he tries to persuade his audience to pay tax without the fair of tax-stealing or corruption.

Moreover, while discussing the difficulty faced by small businesses and small entrepreneurs, he says:

"The cost of doing business is so high and difficult that it discourages any small investment opportunities, we will, In Sha Allah, make it easy for them to invest so that more people get employment".

Imran Khan's effort of presenting his party as a reliable source for the progress of businesses is presented from the use of ' $w e$ ' that refers towards his party; Pakistan Tehreek-e-Insaf which is now in power. He states that his party members "will, In Sha Allah, make" investment opportunities easily available for small businesses so that "more people get employment". The above statement directly points towards the positive self-presentation in order to make his audience believe that he and his party are dependable.

\section{Conclusion}

It is concluded that Imran Khan does use Aristotelian Rhetoric strategies; ethos, pathos and logos, and some other strategies such as Predication strategy and Positive self-presentation and Negative other-presentation strategy in his speech so as to achieve his political agendas by persuading the audience, first, into making believe 
them in the presented ideologies and then, to act accordingly. As the best tool for persuasion is language and speech, Imran Khan skillfully puts words together and speaks eloquently for the achievement of personal or political objectives. Thus, his victory speech employed well rhetoric is determined using Aristotle's rhetoric, Predication strategy, and Positive self and Negative other presentation through the tactful use of lexicons.

Since language plays an essential role in politics as every political action is planned, accompanied, influenced and brought about by language, Imran Khan's victory speech is ideologically loaded, and through it, he tries instilling these ideologies in people's minds. In this regard, Imran Khan, as other political leaders, uses different persuasive strategies with a view to persuading his audience along with affecting their prior opinions by carefully using a variety of words.

\section{References}

Aazam, F., Baig, F. Z., Baig, T., Khaliq, S., Azam, A., Shamshad, S., \& Aslam, M. Z. (2019). A Critical Discourse Analysis of 'Fire and Fury: Inside the Trump White House' by Michael Wolff. International Journal of English Linguistics, 9(4), 192-199. https://doi.org/10.5539/ijel.v9n4p192

Alghamdi, N. A., \& Rand, A. (2019). Cross-Cultural Linguistic Analysis of Persuasive Techniques in Shark Tank. International Journal of English Language Education, 7(2), 82-107. https://doi.org/10.5296/ijele.v7i2.15416

Baig, F. Z., Aslam, M. Z., Yaseen, T., Ahmad, H. S., Murtaza, M., \& Abbas, M. J. (2020). Practicing Language Therapy for Effective Simultaneous Bilingualism: Case Studies. International Journal of English Linguistics, 10(1), 230-240. https://doi.org/10.5539/ijel.v10n1p230

Baig, F. Z., Umer, S., Aslam, M. Z., Razaq, M. S., Khan, S. \& Ahmad, Ahmed, T. (2020). Humor as Monotony Breaker in Funny Ads: A Multi-Modal Discourse Analysis of Ads of Pakistani Ufone \& Jazz Cellular Companies. International Journal of English Linguistics, 10(1), 69-80. https://doi.org/10.5539/ijel.v10n1p69

Baig, F. Z., Yousaf, W., Aazam, F., Shamshad, S., Fida, I., \& Aslam, M. Z. (2019). Power, Ideology and Identity in Digital Literacy: A Sociolinguistic Study. International Journal of English Linguistics, 9(2), 252-264. https://doi.org/10.5539/ijel.v9n4p252

Hamidi, H., \& Mirzaee, S. (2012). Critical Discourse Analysis and Fairclough's Model. International Electronic Journal for the Teachers of English, 2(5), 182-190. Retrieved January 21, 2020, from https://www.academia.edu/2645766/Critical_Discourse_Analysis_and_Faircloughs_Model-_Mirzaee_and_ Hamidi_2012_

Horvath, J. (2009). Critical discourse analysis of Obama's political discourse (pp. 22-23). Language, Literature, and Culture in a Changing Transatlantic World International Conference Proceedings, University Library of Prešov University. Retrieved January 28, 2020, from http://www.cs.columbia.edu/ sbenus/Teaching/APTD/Horvath_CDO_Obama.pdf

Khalil, U., Islam, M., Chattha, S. A., \& Qazalbash, F. (2017). Persuasion and Political Discourse: A Critical Discourse Analysis of Imran Khan's Election Speech. Pakistan Vision, 18(2), 193-210. https://doi.org/10.1080/17405904.2019.1665079

Ko, D. H. (2015). Political persuasion: Adopting Aristotelian rhetoric in public policy debate strategies. International Journal of Humanities and Social Science, 5(10), 114-123. Retrieved February 1, 2020, from http://www.ijhssnet.com/journals/Vol_5_No_10_October_2015/12.pdf

News Desk. (2018, July 26). The Express Tribune: Imran's victory speech hailed as 'mature' and 'encouraging' by Twitterati. Retrieved from https://tribune.com.pk/story/1766970/1-imrans-victory-speech-hailed-mature-encouraging-twitterati/

Norali, N., \& Rezaei, S. (2016). Language and power: The use of persuasive techniques in Iran and U.S. President Speeches. Journal of Language Teaching and Research, 7(6), 1203-1209. https://doi.org/10.17507/jltr.0706.19

Nurrosyidah, H. Y. (2016). Persuasive Strategies in Joko Widodo's Political Speeches. Master's thesis, Maulana Malik Ibrahim State Islamic University Malang. Retrieved January 12, 2020, from https://pdfs.semanticscholar.org/4c25/0e3206390842ea8a3f2d57d8afd69a50da5f.pdf

Partington, A. (2003). Politics, power, and politeness. In A. Partington (Ed.), The linguistics of political argument (pp. 124-155). London and New York: Routledge. https://doi.org/10.4324/9780203218259 
Sharif, A. (2015). Persuasive Discourse in Ceremonial Speeches of Mother Teresa. Doctoral thesis, Universiti Putra Malaysia. Retrieved January 29, 2020, from http://psasir.upm.edu.my/id/eprint/57832/1/FBMK\%202015\%2039RR.pdf

Ting, S. (2018). Ethos, Logos and Pathos in University Students' Informal Requests. Journal of Language Studies, 18(1), 234-251. http://doi.org/10.17576/gema-2018-1801-14

Van Dijk, T. A. (1997). What is political discourse analysis. Belgian Journal of Linguistics, 11(1), 11-52. https://doi.org/10.1075/bjl.11.03dij

Van Dijk, T. A. (2001). 18 Critical discourse analysis. The Handbook of Discourse Analysis, 349-371. https://doi.org/10.1002/9780470753460.ch19

Van Dijk, T. A. (2016). Socio-cognitive Discourse Studies. In R. John \& F. John (Eds.), Handbook of Discourse Analysis (pp. 1-26). London: Routledge. https://doi.org/10.4324/9781315739342-3

\section{Copyrights}

Copyright for this article is retained by the author, with first publication rights granted to the journal.

This is an open-access article distributed under the terms and conditions of the Creative Commons Attribution license (http://creativecommons.org/licenses/by/4.0/). 